\title{
Original article (Orijinal araştırma) \\ New records of the parasitoids of Drosophila suzukii (Matsumura, 1931) (Diptera: Drosophilidae) in newly invaded areas in Turkey: molecular identification
}

\author{
Türkiye'de yeni istila edilen alanlarda Drosophila suzukii (Matsumura, 1931) (Diptera: \\ Drosophilidae)'nin yeni parazitoit kayıtları: moleküler tanımlamaları
}

\section{Gülay KAÇAR ${ }^{1^{*}}$}

\begin{abstract}
Drosophila suzukii (Matsumura, 1931) (Diptera: Drosophilidae) is an invasive pest species of various fruit crops in the USA and Europe. Although D. suzukii has been recently reported in strawberry in Erzurum and other newly invaded areas in Turkey (e.g., Ankara, Bolu, Çanakkale and Düzce), there is only limited information on its indigenous parasitoids. In this study, four hymenopteran parasitoids, the larval parasitoids of Leptopilina boulardi (Barbotin, Carton \& KelnerPillault, 1979), Leptopilina heterotoma (Thomson, 1862) (Figitidae) and the pupal parasitoids of Pachycrepoideus vindemmiae (Rondani, 1875) (Pteromalidae) and Trichopria drosophilae (Perkins, 1910) (Diapriidae), were collected from frugivorous drosophilid species. Leptopilina boulardi and $T$. drosophilae were found for the first time in Turkey. Leptopilina heterotoma and $P$. vindemmiae were the most common parasitoid species, reared from field-collected fruit samples in this study. The laboratory assays revealed that both pupal parasitoids developed from $D$. suzukii pupae, but the association of $L$. heterotoma and $L$. boulardi with $D$. suzukii is yet to be confirmed. The PCR amplification of the cytochrome $c$ oxidase subunit I loci of mtDNA of the representative four parasitoid samples produced different lengths of DNA fragments, ranging from $633 \mathrm{bp}$ to $658 \mathrm{bp}$. BLASTn queries based on the COI of the parasitoid samples showed that the sequences were $99-100 \%$ identical to those of the corresponding species in the GenBank database.
\end{abstract}

Keywords: Molecular diagnostic, new parasitoids, spotted wing drosophila, Turkey

\section{Öz}

Drosophila suzukii (Matsumura, 1931) (Diptera: Drosophilidae), Avrupa ve Amerika'da çeşitli meyvelerde zarara neden olan istilacı bir türdür. Drosophila suzukii, son zamanlarda Türkiye'de Erzurum'da çilekte rapor edilmesine ve o zamandan beri yeni alanları (Ankara, Bolu, Çanakkale ve Düzce vs.) istila etmesine rağmen, onun yerli parazitoitleri çok az bilinmektedir. Bu çalışmada, dört hymenopter parazitoit, larval parazitoitler Leptopilina boulardi (Barbotin, Carton \& Kelner-Pillault, 1979), Leptopilina heterotoma (Thomson, 1862) (Figitidae) ve pupal parazitoitler Pachycrepoideus vindemmiae (Rondani, 1875) (Pteromalidae) ve Trichopria drosophilae (Perkins, 1910) (Diapriidae) türleri, meyvelerde bulunan drosophilid türlerinden elde edilmiştir. Leptopilina boulardi ve $T$. drosophilae türlerinin Türkiye'de ilk defa varlığı belirlenmiştir. Leptopilina heterotoma ve $P$. vindemmiae, toplanan örneklerden en fazla bulunan türler olmuştur. Laboratuvar denemeleri iki pupa parazitoitinin $D$. suzukii pupalarından geliştiğini belirlenmesine rağmen, $L$. heterotoma ve $L$. boulardi'nin $D$. suzukii'den geliştiklerini hala doğrulanamamıştır. Dört parazitoit türü temsil eden örneklerin mitokondrial DNA'sının cytochrome c oxidase subunit I lokusunun PCR ile çoğaltılması sonucu 633 bp ile 658 bp arasında DNA segmentlerini ürettiği belirlenmiştir. Bu ürünlerin BLASTn analizi sonucu GenBank'daki referans bireylerin sekanslarıyla \%99-100 benzerliğe sahip olduğu tespit edilmiştir.

Anahtar sözcükler: Moleküler tanımlama, yeni parazitoitler, noktalı kanatlı drosophila, Türkiye

\footnotetext{
${ }^{1}$ Bolu Abant Izzet Baysal University, Faculty of Agriculture and Natural Sciences, Department of Plant Protection, 14030, Bolu, Turkey

* Corresponding author (Sorumlu yazar) e-mail: gulaysahan@yahoo.com

Received (Alınış): 20.08.2019 Accepted (Kabul ediliş): 15.11.2019 


\section{Introduction}

Drosophila suzukii (Matsumura, 1931) (Diptera: Drosophilidae), which is primarily known as spotted wing drosophila in the USA and indigenous to southeast Asia (Kanzawa, 1939), has rapidly spread to Europe, South and North America (Bolda et al., 2010; Hauser, 2011; Walsh et al., 2011; Berry, 2012; Depra et al., 2014; Emiljanowicz et al., 2014). After the fly was first found in Spain and Italy in 2008 (Walsh et al., 2011), D. suzukii has increasingly spread into many other countries of Europe, such as Croatia, France, Portugal and Slovenia (Milek et al., 2011; Withers \& Allemand, 2012). In Turkey, it was first recorded in Erzurum in 2014 (Orhan et al., 2016; Tozlu et al., 2016), and further found Ankara in 2015 (Önder et al., 2016), Bolu and Düzce in 2016 (Kaçar \& Koca, 2017), Karaman in 2017 (Ögür et al., 2018) and Çanakkale in 2018 (Efil, 2018; Kasap \& Özdamar, 2019). Drosophila suzukii appears to be spreading rapidly in Turkey. The most probable reason for this rapid spread is the international trade of infested fruits (EPPO, 2002; Westphal et al., 2008). D. suzukii is an extremely polyphagous invasive pest which principally damages soft-skinned fruits (Lee et al., 2011). The female of $D$. suzukii lays eggs in undamaged fruit owing to the serrated female ovipositor (Sasaki \& Sato, 1995). Thus, it usually lays eggs on ripe fruit (Mitsui et al., 2007). Drosophila suzukii causes physical damage to fresh fruit by means of secondary pathogen infections, which can access the damaged skin of the fruit and cause faster deterioration, resulting in the yield losses of 30 $100 \%$ in fruit production (Bolda et al., 2010).

Drosophila species are attacked by about 50 hymenopteran parasitoids which have an important function in controlling the drosophilids (Carton et al., 1986). Hymenopteran parasitoids mostly from the genera Asobara (Braconidae), Leptopilina and Ganaspis (Figitidae), Trichopria (Diapriidae), and Pachycrepoideus (Pteromalidae) commonly parasitize drosophilids (Carton et al., 1986; Hertlein, 1986). Several larval parasitoids, including Leptopilina boulardi (Barbotin, Carton \& Kelner-Pillault, 1979), Leptopilina heterotoma (Thomson, 1862), Leptopilina japonica Novković \& Kimura, 2011, Leptopilina japonica formosana Novković \& Kimura, 2011, Asobara japonica Belokobylskij, 1998, Asobara brevicauda Guerrieri, Giorgini, Cascone, Carpenito \& Achterberg, 2016, Asobara leveri (Nixon, 1939), Asobara tabida (Nees, 1834), Ganaspis xanthopoda (Ashmead, 1896) and Ganaspis brasiliensis (Ihering, 1905), and pupal parasitoids; e.g., Pachycrepoideus vindemmiae (Rondani, 1875) (Pteromalidae) and Trichopria drosophilae (Perkins, 1910) (Diapriidae), are commonly associated with Drosophila species (Fleury et al., 2004; Mitsui et al., 2007; Chabert et al., 2012; Novkovic et al., 2011; Poyet et al., 2013; Kimura \& Novkovic, 2015; Daane et al., 2016; Girod et al., 2018a, b, c; Giorgini et al., 2019). Recently, several studies conducted in the USA and European countries have shown that most of the larval drosophila parasitoids are unable to successfully develop in D. suzukii (Chabert et al., 2012; Poyet et al., 2013; Rossi Stacconi et al., 2013; Girod et al., 2018a, b, c; Giorgini et al., 2019). Asobara japonica successfully developed in D. suzukii compared with other widespread larval parasitoids ( $A$. tabida and $G$. xanthopoda) although $L$. heterotoma may be country-specific (Mitsui et al., 2007; Kimura \& Novkovic, 2015; Rossi Stacconi et al., 2015; Girold et al., 2018). Only two pupal parasitoids, $P$. vindemmiae and $T$. drosophilae, readily attack D. suzukii (Rossi Stacconi et al., 2015, 2017; Kaçar et al., 2017). Although T. drosophilae is polyphagous parasitoid, it may be one candidate for controlling populations of D. suzukii (Girod et al., 2018c; Rossi Stacconi et al., 2018).

The parasitoids of the order Hymenoptera are generally identified according to their morphological characteristics, which leads to challenges in diagnosis due to their body size and undefined characteristics (Tomanovic et al., 2003). The molecular analysis of DNA sequences is considered as a complementary tool for the morphological identification of insects (Farrokhzadeh et al., 2014). Molecular identification has allowed quick recognition, distinction and identification of diverse species based on the DNA sequencing of single samples. However, since researchers perform the identification of species using only key morphological characteristics, the results may not be definitive and they are mostly at genus level. The molecular techniques recently developed allow identification of insects at the species level. For example, the cytochrome c oxidase subunit I (COI) locus of mitochondrial DNA has been employed as a reliable tool to accurately identify parasitoid species (Fre'zal \& Leblois, 2008; Linares et al., 2009). 
The current study aimed to explore and identify drosophilid parasitoids in different geographical regions of Turkey and present an alternative identification technique for these parasitoids based on phenotypic characteristics to support diagnoses.

\section{Materials and Methods}

\section{Collection areas and methods}

The survey for the parasitoids of frugivorous drosophila was conducted in two provinces in Turkey, Bolu and Düzce, from May 2016 to December 2018. The samples of drosophilids and parasitoids were collected from infested fresh and fallen decaying fruit (including apples, blackberries, cherries, figs, grapes, pears, persimmons, plums, raspberries and strawberries) in the field. Samples were collected during or after the harvesting seasons for each fruit. The fruit samples were placed in a cooler box to be transferred to a climate room. The location, date and collector were recorded, and each fruit sample was labeled accordingly. The fruit samples collected in the field were separately put in transparent containers with ventilated lids on a layer of moist filter paper until pupation.

All fly pupa reared from the field-collected larvae were inspected and separately placed in 5-cm Petri dishes until the appearance of drosophilid adults or parasitoids which were preserved in alcohol (95\%) for later identification. The samples were kept in a climate cabin at $40-70 \% \mathrm{RH}, 22 \pm 3^{\circ} \mathrm{C}$ and $12: 12-\mathrm{h} \mathrm{L}: \mathrm{D}$ photoperiod with natural light in the laboratory. Four parasitoid species were paired and maintained on $D$. suzukii and Drosophila melanogaster (Meigen, 1830) supplied with artificial food of $10 \%$ honey-water provided for the parasitoids with wet paper towel in plastic container as additional water source. The flies were collected from the field fruits in Düzce and provided an artificial corn meal (Dalton et al., 2011). Petri dishes $(9 \mathrm{~cm})$ were filled with $35 \mathrm{~g}$ of artificial diet were placed in cages as an oviposition media and changed in every $2 \mathrm{~d}$. These were used for rearing drosophilids and their parasitoids. The parasitoid species were tested in the laboratory to confirm their suitability as a host for $D$. suzukii. Emerged parasitoids were separated in $L$. heterotoma and $L$. boulardi males and females. Each parasitoid pair were individually released, as soon as they were collected, in rearing tubes with drosophila medium and 10 D. suzukii 1-2-d old larvae or pupae and honey-water droplets for confirming tests. After all parasitoids had emerged, all dead unemerged pupae were dissected. The majority of emerged flies (notably those from the same dishes where were parasitoids have emerged) were preliminary identified.

\section{Molecular identification of the parasitoids}

The fly species were identified using the identification key according to Markow \& O'Grady (2006). $D$. suzukii pupae were distinguished considering the existence of a couple of distinct breathing tubes on the anterior end (Kanzawa, 1939). The parasitoids species were identified using the identification key described by Legner et al. (1976), Boucek \& Rasplus (1991) and Carton et al. (1986). The identification of the four parasitoids were confirmed by all experts. The figitids were identified by Dr. Mattias Forshage and deposited with the Entomology Collection of the Swedish Museum of Natural History (Stockholm, Sweden). Trichopria drosophilae was confirmed or identified by Dr. Ovidiu Gavrilovici (Department of Psychology and Education Sciences, Universitatea Alexandru Ioan Cuza, Iaşi, Romania). Pachycrepoideus vindemmiae were confirmed or identified by Dr. Habil Mircea-Dan Mitroiu (Biology Faculty, Alexandru loan Cuza University, Romania). All parasitoid samples were also deposited at Bolu Abant Izzet Baysal University, Agriculture and Science Faculty, Bolu, Turkey.

The extraction of the nucleic acids of all specimens either dried or preserved in $95 \%$ ethyl alcohol was conducted using a DNeasy Blood and Tissue Kit (Qiagen, Valencia, CA, USA) according to the manufacturer's instructions. The DNA extracts were quantified spectrophotometrically by a DS-11 FX series spectrophotometer (DeNovix Inc., Wilmington, DE, USA) and ultimately diluted to $10 \mathrm{ng} / \mathrm{\mu l}$ using sterile $\mathrm{ddH}_{2} \mathrm{O}$. The PCR amplification based on part on the mitochondrial protein-coding gene and $\mathrm{COI}$ 
gene was performed using the universal primer pair LCO1490 (5'-GGT CAA CAA ATC ATA AAG ATA TTG G-3') and HCO2198 (5'-TAA ACT TCA GGG TGA CCA AAA AAT CA-3') (Folmer et al., 1994). Amplification reactions were conducted in a $50 \mu \mathrm{l}$ reaction mixture containing $5 \mu \mathrm{l} 10 \times \mathrm{PCR}$ reaction buffer, $0.4 \mu \mathrm{M}$ of each primer, $50 \mathrm{ng}$ DNA template, $0.2 \mathrm{mM}$ each dNTPs, and 1.25 unit Taq DNA Polymerase (New England BioLabs, MA, USA; Neb \#M0320S). The amplification program for the COI locus was as follows: an initial denaturation step at $94^{\circ} \mathrm{C}$ for $3 \mathrm{~min}$, followed by 35 cycles at $94^{\circ} \mathrm{C}$ for $30 \mathrm{~s}, 52^{\circ} \mathrm{C}$ for $30 \mathrm{~s}$ and $72^{\circ} \mathrm{C}$ for 1 min, and a 5-min final extension at $72^{\circ} \mathrm{C}$. All the PCR products were confirmed electrophoretically using agarose gel $(1.2 \% \mathrm{w} / \mathrm{v})$ and purified using the Wizard SV Gel and PCR Clean-Up System (Promega, Madison, WI, USA) following the manufacturer's instructions. The DNA fragments were sequenced by the Sanger nucleotide sequencing method provided by a commercial company (Macrogen Inc., Seoul, South Korea).

The resulting sequences were aligned with ClustalW, which is a multiple sequence alignment method (Thompson et al., 1994). The sequences were analyzed and BLAST-searched against GenBank for the identification of the closest presented reference sequences in the NCBI nucleotide collection (http://blast.ncbi.nlm.nih.gov/Blast). The phylogenetic analyses of the sequences and reference sequences available in GenBank were performed using the MEGA 7 software (Kumar et al., 2016). A neighbor-joining tree was constructed using Tamura \& Nei's (1993) model with 1000 bootstrap replicates. The sequence of Trichogramma evanescens Westwood, 1833 (Hymenoptera: Trichogrammatidae) was included as the out group to root the phylogenetic tree.

\section{Results and Discussion}

The adult parasitoid species were determined in field-collected drosophilid specimens from various fruit samples. In the present study, four drosophilid parasitoid species were collected from Bolu and Düzce and identified as $L$. boulardi and $L$. heterotoma, and $P$. vindemmiae and $T$. drosophilae, which are new to the fauna of Turkey (Figure 1). Both pupal parasitoids are usually solitary; $P$. vindamiae is ectophagous but T. drosophilae is endophagous (Legner et al., 1976). Four parasitoid species were determined from the field-collected fruit samples from Düzce: $L$. boulardi from strawberry, $P$. vindemmiae from wild blackberry in 2016, and L. heterotoma and T. drosophilae from pear in 2017 (Figure 1). Leptopilina heterotoma from a yellow plum in 2017 and $P$. vindemmiae from apple in 2016 in Bolu. While the laboratory assays confirmed that $P$. vindemmiae and $T$. drosophilae successfully parasitized $D$. suzukii pupae, there was no evidence that the growth of the larval parasitoid, $L$. heterotoma, was associated with $D$. suzukii in the laboratory or field.

Leptopilina species are common parasitoids of Drosophilidae throughout the world (Allemand et al., 2002). Leptopilina individuals are solitary koinobiont endoparasitoid that attacks a single host that continues feeding and growing during parasitism (van Noort et al., 2015; Harvey et al., 2016). The typical Leptopilina are often superficially similar to Ganaspis. Leptopilina males have the third and fourth antennomeres slightly curved and have a distinct hair tuft on the metapleural corner (van Noort et al., 2015). Leptopilina heterotoma and L. boulardi are the most known parasitoids in Africa, Asia, Europe and North America, attack drosophilid hosts, especially $D$. melanogaster, but neither developed from the immune resistance of SWDs under laboratory conditions (Chabert et al., 2012; Poyet et al., 2013; van Noort et al., 2015). However, $T$. drosophilae and $P$. vindemmiae attack the pupae of $D$. suzukii and can effectively parasitize in the laboratory (Kaçar et al., 2017; Rossi Stacconi et al., 2017). Pachycrepoideus vindemmiae was reported that the generalist solitary ectoparasitoid which attacked more than 60 fly species (Carton et al., 1986; Hanson \& Gauld, 1995; Wang \& Messing, 2004). The parasitism rate of $P$. vindemmiae was found over $80 \%$ in raspberries in laboratory tests (Chabert et al., 2012; Gabarra et al., 2015). Pachycrepoideus vindemmiae was also highly reproduced in D. suzukii in the laboratory (Rossi Stacconi et al., 2015). Trichopria drosophilae is an idiobiont endoparasitoid specialized in fruit drosophilids (Carton et al., 1986; Chabert et al., 2012; Wang et al., 2016). Of the parasitoids, T. drosophilae has been reported several times in the USA and Europe and proven to attack either D. melanogaster or D. suzukii (Gabarra et al., 2015; 
Rossi Stacconi et al., 2015; Mazzetto et al., 2016). Currently, this species is considered to be one of the best candidate parasitoids for the biological control of $D$. suzukii. Field trials in Italy showed that $T$. drosophilae is widely spread all over the country and presents as the promising candidate for the augmentative control of $D$. suzukii in fields (Mazzetto et al., 2016; Rossi Stacconi et al., 2018).
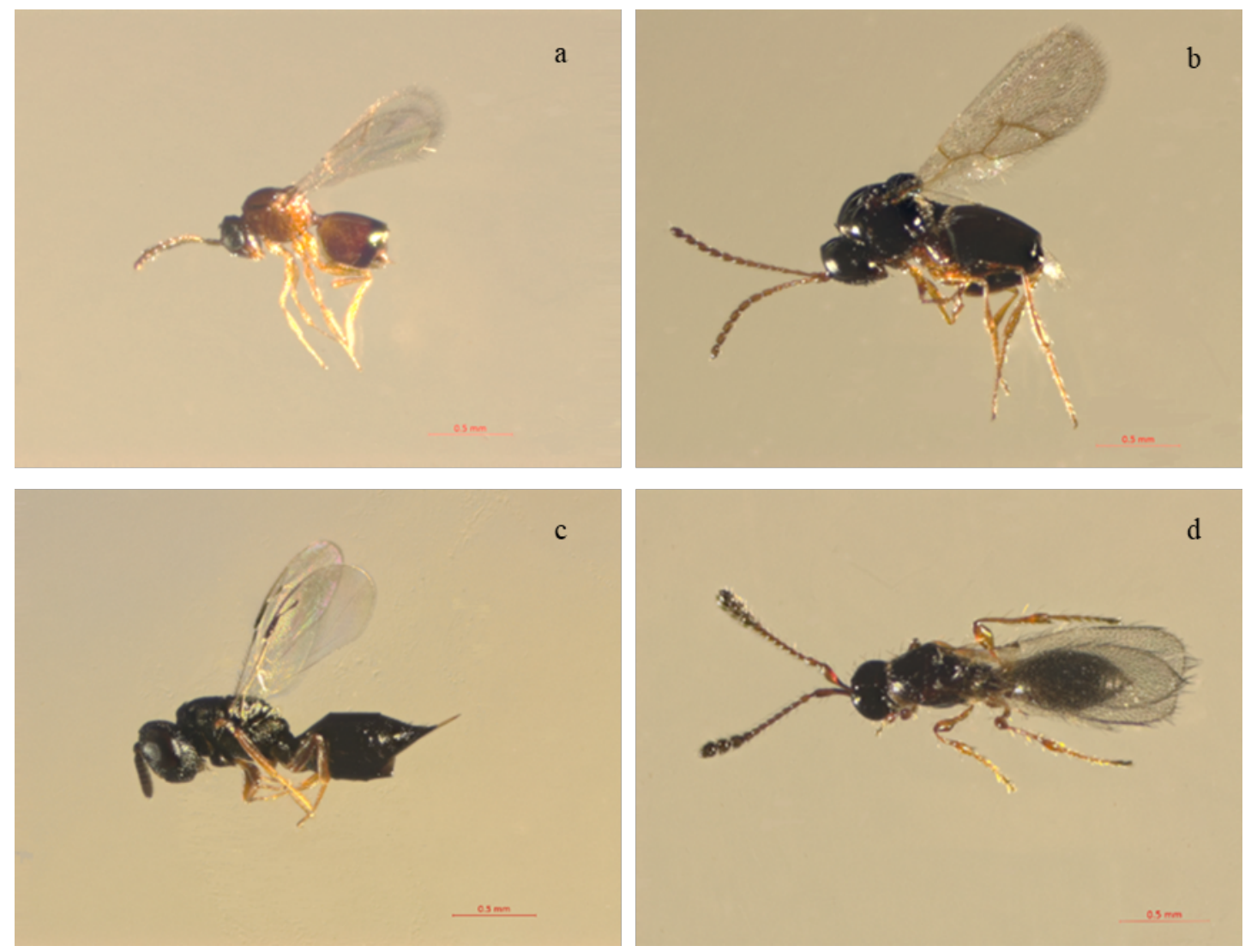

Figure 1. a) Leptopilina boulardi Barbotin, Carton \& Keiner-Pillault $Q_{+}$; b) Leptopilina heterotoma Thomson $\hat{O}^{\text {; }}$ c) Pachycrepoideus vindemmiae (Rondani) $\circ$; d) Trichopria drosophilae Perkins + .

The PCR amplification of the COI loci of the mtDNA of the representative parasitoid samples produced different lengths of DNA fragments, ranging from 633 to $658 \mathrm{bp}$. The BLASTn queries based on the $\mathrm{COI}$ of the samples showed that the sequences were $99-100 \%$ identical to those of the corresponding species in the database of GenBank. There were two sequences of Trichopria sp. matching the current sequence at $641 / 642$ sequence identity. The sequences data were deposited in the GenBank with the accession numbers of MK798163, MK813907, MK798164 and MK798165 for the T. drosophilae, P. vindemmiae, $L$. boulardi, and $L$. heterotoma samples, respectively. Morphologically cryptic species are known in L. heterotoma (Novkovic et al., 2011). The phylogenetic tree was included these cryptic species. Dzc06 was on a branch with a clone from Sapporo, Japan (AB583568). Phylogenetic analyses based on the $\mathrm{COI}$ sequences of the samples obtained from this study and the reference sequences of the corresponding species found in the GenBank indicated that the samples belonging to the same species were clearly separated from each other and T. evanescens with a bootstrap support of $100 \%$ (Figure 2). 


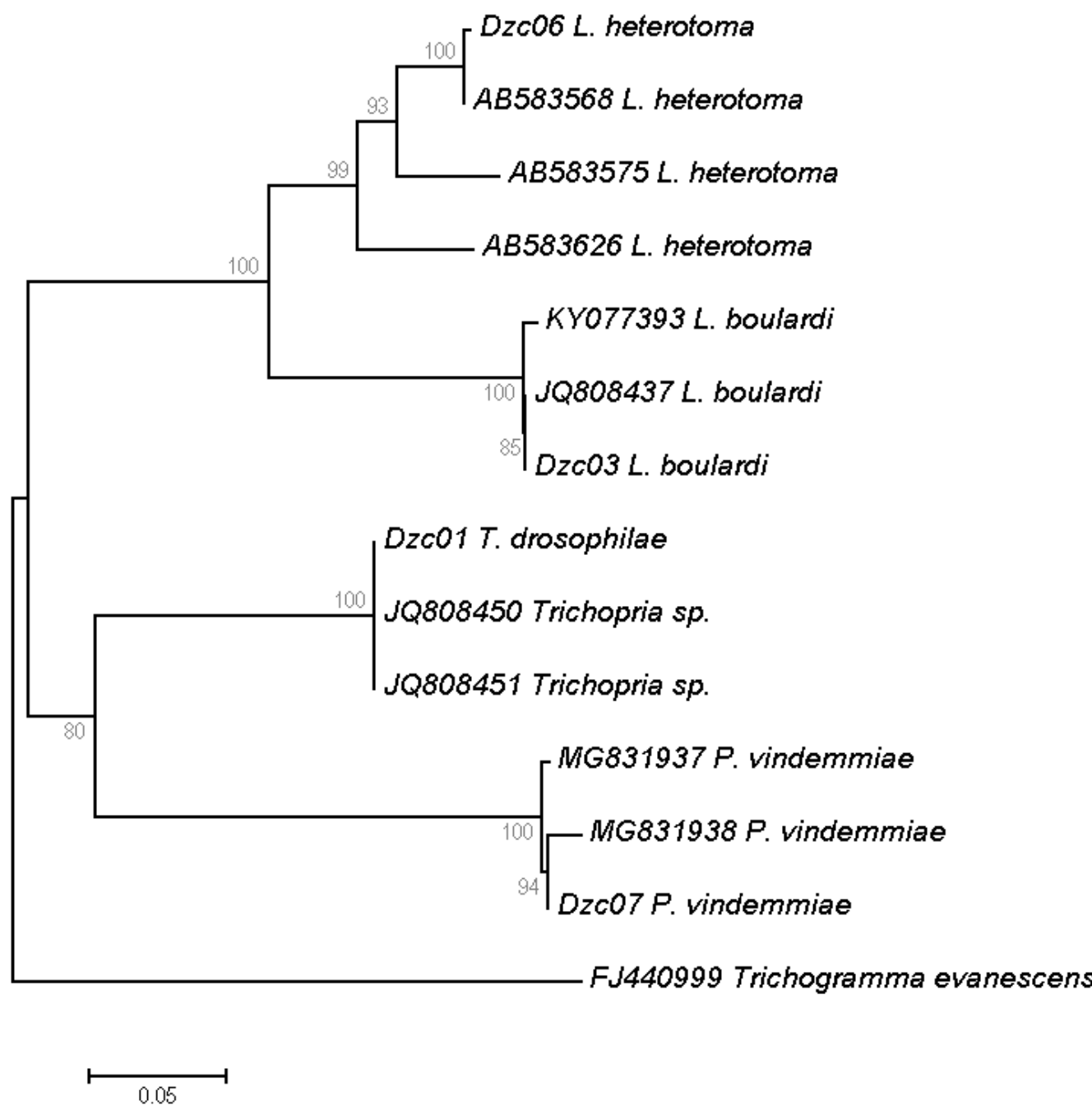

Figure 2. Phylogeny of the parasitoids associated with Trichogramma evanescens Westwood based on the COI locus (neighborjoining). The bootstrap values (percentage, based on 1000 replicates) are shown on the branches.

Drosophila suzukii is a new quarantine fly pest attacking all types of fruit throughout the world. This fly is one of the serious economic pests that especially damage soft fruit. The native parasitoids of $D$. suzukii significant contribute to its management worldwide, but they are not fully known in Turkey. In the current study, two drosophilid parasitoids were determined in geographical areas that had not been previously surveyed. In this study, rather than morphological identification, the molecular diagnostic method was used for the drosophilid parasitoid species of $D$. suzukii since it is a faster and easier alternative identification technique. The pupae of $D$. suzukii were successfully parasitized by $P$. vindemmiae and $T$. drosophilae according to the laboratory experiments. However, further investigations are needed to offer more definite results related to larval parasitoids.

\section{Acknowledgments}

The author thanks to Assoc. Prof. Göksel Özer (Bolu Abant Izzet Baysal University, Agriculture and Science Faculty, Bolu, Turkey) for cooperation with the molecular identification. 


\section{References}

Allemand, R., C. Lemaître, F. Frey, M. Boulétreau, F. Vavre, G. Nordlander, J. van Alphen \& Y. Carton, 2002. Phylogeny of six African Leptopilina species (Hymenoptera: Cynipoidea, Figitidae), parasitoids of Drosophila, with description of three new species. Annales de la Société Entomologique de France, 38: 319-332.

Berry, J. A., 2012. Pest Risk Assessment: Drosophila suzukii: spotted wing drosophila (Diptera: Drosophilidae) on fresh fruit from the USA. Ministry for Primary Industries. MPI Technical Paper No: 2012/05, New Zealand Government, Ministry for Primary Industries. (Web page: www.mpi.govt.nz/documentvault/2897) (Date accessed: August 2019).

Bolda, M., R. E. Goodhue \& F. G. Zalom, 2010. Spotted wing drosophila: potential economic impact of a newly established pest. Giannini Foundation of Agricultural Economics, University of California Agricultural and Resource Economics, 13: 5-8.

Boucek, Z. \& J. Y. Rasplus, 1991. Illustrated Key to West-Palearctic Genera of Pteromalidae (Hymenoptera: Chalcidoidea). INRA, Paris, 140 pp.

Carton, Y., M. Boule'treau, J. J. M. Van Alphen \& J. C. van Lenteren, 1986. "The Drosophila Parasitic Wasps, 347394". In: The Genetics and Biology of Drosophila (Eds. M. Ashburner, H. L. Carson \& J. N. Thompson) Volume 3e. Academic Press, New York, USA, 430 pp.

Chabert, S., R. Allemand, M. Poyet, P. Eslin \& P. Gibert, 2012. Ability of European parasitoids (Hymenoptera) to control a new invasive Asiatic pest, Drosophila suzukii. Biological Control, 63: 40-47.

Daane, K. M., X. G. Wang, A. Biondi, B. Miller, J. C. Miller, H. Riedl, P. W. Shaerer, E. Guerrieri, M. Giorgini, M. Buffıngton, K. van Achterberg, Y. Song, T. Kang, H. YI, C. Jung, D. W. Lee, B. Chung, K. A. Hoelmer \& V. M. Walton, 2016. First exploration of parasitoids of Drosophila suzukii in South Korea as potential classical biological agents. Journal of Pest Science, 89: 823-835.

Dalton, D. T., V. M. Walton, P. W. Shearer, D. B. Walsh, J. Caprile \& R. Isaacs, 2011. Laboratory survival of Drosophila suzukii under simulated winter conditions of the Pacific Northwest and seasonal field trapping in five primary regions of small and stone fruit production in the United States. Pest Management Science, 67: 1368-1374.

Depra, M., J. L. Poppe, H. J. Schmits, C. Toni \& V. L. S. Valente, 2014. The first records of the Drosophila suzukii invasive pest in the South American continent. Journal of Pest Sciences, 87: 379-383.

Efil, L., 2018. Çanakkale İli çilek alanlarında yeni bir zararlı Drosophila suzukii (Matsumura) (Diptera: Drosophilidae)'nin yayılış alanları ve bulaşıklıı̆ı. Türk Tarım ve Doğa Bilimleri Dergisi, 5 (3): 280-284.

Emiljanowicz, L. M., G. D. Ryan, A. Langille \& J. Newman, 2014. Development, reproductive output and population growth of the fruit fly pest Drosophila suzukii (Diptera: Drosophilidae) on artificial diet. Journal of Economic Entomology, 107 (4): 1392-1398.

EPPO, 2002. Drosophila suzukii (DROSSU). (Web page: https://gd.eppo.int/taxon/DROSSU) (Date accessed: August 2019).

Farrokhzadeh, H., G. Moravvej, M. M. Awal \& J. Karımı, 2014. Molecular and morphological identification of hymenoptran parasitoids from the pomegranate aphid, Aphis punicae in RazavinKhorasan province, Iran. Turkish Journal of Entomology, 38 (3): 291-306.

Fleury, F., N. Ris, R. Allemand, P. Fouillet, Y. Carton \& M. Boule'treau, 2004. Ecological and genetic interactions in Drosophila-parasitoids communities: a case study with $D$. melanogaster, $D$. simulans and their common Leptopilina parasitoids in southeastern France. Genetica, 120 (1-3):181-194.

Folmer, O., M. Black, W. Hoeh, R. Lutz \& R. Vrijenhoek, 1994. DNA primers for amplification of mitochondrial cytochrome c oxidase subunit I from diverse metazoan invertebrates. Molecular Marine Biology and Biotechnology, 3 (5): 294-299.

Fre'zal, L. \& R. Leblois, 2008. Four years of DNA barcoding: current advances and prospects. Infection, Genetics and Evolution, 8: 727-736.

Gabarra, R., J. Riudavets, G. A. Rodriguez, J. Pujade-Villar \& J. Arno, 2015. Prospects for the biological control of Drosophila suzukii. Biocontrol, 60: 331-339.

Giorgini, M., X. G. Wang, Y. Wang, F.-S. Chen, E. Hougardy, E., H.-M.-Zhang, Z.-Q. Chen, H.-Y. Chen, C.-X. Liu, P. Cascone, G. Formisano, G. A. Carvalho, A. Biondi, M. Buffington, K. M. Daane, K. A. Hoelmer \& E. Guerrieri, 2019. Exploration for native parasitoids of Drosophila suzukii in China reveals a diversity of parasitoid species and narrow host range of the dominant parasitoid. Journal of Pest Science, 92: 509-522. 
Girod, G., O. Lierhmann, T. Urvois, T. C. J. Turlings, M. Kenis \& T. Haye, 2018a. Host specifcity of Asian parasitoids for potential classical biological control of Drosophila suzukii. Journal of Pest Science, 91: 1241-1250.

Girod, P., N. Borowiec, M. Buffington, G. Chen, Y. Fang, M. T. Kimura, F. J. Peris-Felipo, N. Ris, H. Wu, C. Xiao, J. Zhang, A. Aebi, T. Haye \& M. Kenis, 2018b. The parasitoid complex of D. suzukii and other fruit feeding Drosophila species in Asia. Scientific Reports, 8: 11839.

Girod, P., L. Rossignaud, T. Haye, T. C. J. Turlings \& M. Kenis, 2018c. Development of Asian parasitoids in larvae of Drosophila suzukii feeding on blueberry and artificial diet. Journal of Applied Entomology, 142: 483-494.

Hanson, P. E. \& I. D. Gauld, 1995. The Hymenoptera of Costa Rica. Oxford University Press, Oxford, UK, 893 pp.

Harvey, J. A. M. Fei, M. Lammers, M. Kos, F. Zhu, R. Heinen, E. H. Poelman \& R. Gols, 2016. Development of a solitary koinobiont hyperparasitoid in different instars of its primary and secondary hosts. Journal of Insect Physiology, 90: 36-42.

Hauser, M., 2011. A historic account of the invasion of Drosophila suzukii (Matsumura) (Diptera: Drosophilidae) in the continental United States, with remarks on their identification. Pest Management Science, 67: 1352-1357.

Hertlein, M. B., 1986. Seasonal development of Leptopilina boulardi (Hymenoptera: Eucoilidae) and its hosts Drosophila melanogaster and D. simulans in California. Environmental Entomology, 15: 859-866.

Kaçar, G. \& A. S. Koca, 2017. "First recording of spotted wing drosophila in Bolu and Düzce of Turkey and moleculer identification, 66”. II. International Iğdır Symposium (9-11 October 2017, Iğdır, Turkey), 488 pp.

Kaçar, G., X. G. Wang, A. Biondi \& K. M. Daane, 2017. Linear functional response by two pupal Drosophila parasitoids foraging within single or multiple patch environments. PLoS One, 12 (8): e0183525.

Kanzawa, T., 1939. Studies on Drosophila suzukii Mats. Yamanashi Prefecture Agricultural Experimental Station, Kofu, Japan, 49 pp. (Web page: www.cabdirect.org/cabdirect/abstract/19410501073) (Date accessed: August 2019).

Kasap, İ. \& E. Özdamar, 2019. Population development of Drosophila suzukii (Matsumura) (Diptera: Drosophilidae) in vineyards of Çanakkale Province. Turkish Journal of Entomology, 43 (1): 57-62.

Kimura, M. T. \& B. Novkovic, 2015. Local adaptation and ecological fitting in host use of the Drosophila parasitoid Leptopilina japonica. Ecological Research, 30: 499-505.

Kumar, S., G. Stecher \& K. Tamura, 2016. MEGA7: molecular evolutionary genetics analysis version 7.0 for bigger datasets. Molecular Biology and Evolution, 33 (7): 1870-1874.

Lee, J. C., D. J. Bruck, H. Curry, D. Edwards, D. R. Haviland, R. A. van Steenwyk \& B. M. Yorgey, 2011. The susceptibility of small fruits and cherries to the spotted-wing drosophila, Drosophila suzukii. Pest Management Science, 67: 1358-1367.

Legner, E. E., I. Moore \& G. S. Olton, 1976. Tabular keys \& biological notes to common parasitoids of synanthropic Diptera breeding in accumulated animal wastes. Entomological News, 87 (5/6): 113-144.

Linares, M. C., N. I. Soto-Caldero, D. Lees \& N. M. Anthony, 2009. High mitochondrial diversity in geographically widespread butterflies of Madagascar: a test of the DNA barcoding approach. Molecular Phylogenetics and Evolution, 50: 485-495.

Markow, T. \& P. O'Grady, 2006. Drosophila. A Guide to Species Identification and Use. Elsevier Inc., USA, 272 pp.

Mazzetto, F., E. Marchetti, N. Amiresmaeili, D. Sacco, S. Francati, C. Jucker, M. L. Dindo, D. Lupi \& L. Tavella, 2016. Drosophila parasitoids in northern Italy and their potential to attack the exotic pest Drosophila suzukii. Journal of Pest Science, 89: 837-850.

Milek, T. M., G. Seljak, M. Simala \& M. Bjelis, 2011. First record of Drosophila suzukii (Matsumara, 1931) (Diptera: Drosophilidae) in Croatia. (Prvi nalaz Drosophila suzukii (Matsumara, 1931) (Diptera: Drosophilidae) u Hrvatskoj). Glasilo Biljne Zastite, 11 (5): 377-382.

Mitsui, H., K. van Achterberg, G. Nordlander \& M. T. Kimura, 2007. Geographical distributions and host associations of larval parasitoids of frugivorous Drosophilidae in Japan. Journal of Natural History, 41: 1731-1738.

Novkovic, B., H. Mitsui, A. Suwito \& M. T. Kimura, 2011. Taxonomy and phylogeny of Leptopilina species (Hymenoptera: Cynipoidea: Figitidae) attacking frugivorous drosophilid flies in Japan, with description of three new species. Entomological Science, 14: 333-346. 
Ögür, E., L. Ünlü \& F. Canbulat, 2018. New record for spotted wing drosophila, Drosophila suzukii (Matsumura, 1931) (Diptera: Drosophilidae) in Karaman, Central Anatolia. Agriculture \& Forestry, 64 (1): 189-197.

Önder, S., U. Ufuk, R. Orhan, G. Tozlu \& B. Aslantaş, 2016. "Anadolu'da yeni bir meyve zararlısı olan Drosophila suzukii'nin kolanizasyon senaryosu, 36". 23. Ulusal Biyoloji Kongresi (5-9 Eylül 2016, Gaziantep, Türkiye), 472 pp.

Orhan, A., R. Aslantaş, B. S. Önder \& G. Tozlu, 2016. First record of the invasive vinegar fly Drosophila suzukii (Matsumura) (Diptera: Drosophilidae) from eastern Turkey. Turkish Journal of Zoology, 40: 290-293.

Poyet, M., S. Havard, G. Prévost, O. Chabrerie, G. Doury, P. Gibert \& P. Eslin, 2013. Resistance of Drosophila suzukii to the larval parasitoids Leptopilina heterotoma and Asobara japonica is related to haemocyte load. Hysiological Entomology, 38: 45-53.

Rossi Stacconi, M. V., M. Buffington, K. M. Daane, D. T. Dalton, A. Grassia, G. Kaçar, B. Miller, J. C. Miller, N. Baserf, C. Loriatti, V. M. Waltond, N. G. Wimand, X. Wang \& G. Anfora, 2015. Host stage preference, efficacy and fecundity of parasitoids attacking Drosophila suzukii in newly invaded areas. Biological Control, 84: 28-35.

Rossi Stacconi, M. V., A. Grassi, D. T. Dalton, B. Miller, M. Ouantar, A. Loni, C. Ioriatti, V. M. Walton \& G. Anfora, 2013. First field records of Pachycrepoideus vindemiae as a parasitoid of Drosophila suzukii in European and Oregon Small fruit production areas. Entomologia, 1: e3.

Rossi Stacconi, M. V., A. Panel, N. Baser, C. loriatti, T. Pantezzi \& G. Anfora, 2017. Comparative life history traits of indigenous Italian parasitoids of Drosophila suzukii and their effectiveness at different temperatures. Biological Control, 112: 20-27.

Rossi Stacconi, M. V., N. Amiresmaeili, A. Biondi, C. Carli, S. Caruso, M. L. Dindo, S. Francati, A. Gottardello, Grassi, A. Lupi, D. Marchetti, E. Mazzetto, F. Mori, N. Pantezzi, T. Tavella, L. Garzia, G. T. Tonina, L. Vaccari, G. Anfora \& C. Ioriatti, 2018. Host location and dispersal ability of the cosmopolitan parasitoid Trichopria drosophilae released to control the invasive spotted wing drosophila. Biological Control, 117: 188-196.

Sasaki, M. \& R. Sato, 1995. Bionomics of the cherry drosophila, Drosophila suzukii Matsumura (Diptera: Drosophilidae) in Fukushima Prefecture (Japan). Annual Report of the Society of Plant Protection of North Japan, 46: 164-172.

Tamura, K. \& M. Nei, 1993. Estimation of the number of nucleotide substitutions in the control region of mitochondrial DNA in humans and chimpanzees. Molecular Biology and Evolution, 10: 512-526.

Thompson, J. D., D. G. Higgins \& T. J. Gibson, 1994. Clustal W: improving the sensitivity of progressive multiple sequence alignment through sequence weighting, position-specific gap penalties and weight matrix choice. Nucleic Acids Research, 22: 4673-4680.

Tomanovic, Z., N. G. Kavallieratos \& P. Starý, 2003. Aphidius Nees aphid parasitoids (Hymenoptera, Braconidae, Aphidiinae) in Serbia and Montenegro: tritrophic associations and key. Acta Entomologica Serbica, 8: 15-39.

Tozlu, G., R. Aslantaş, B. Ş. Önder \& A. Orhan, 2016. "Türkiye için önemli bir meyve zararılısı: istilacı tür Drosophila suzukii, 260”. Uluslararası Türkiye VI. Bitki Koruma Kongresi (5-8 Eylül 2016, Konya, Türkiye), 938 pp.

Van Noort, S., M. L. Buffington \& M. Forshage, 2015. Afrotropical Cynipoidea (Hymenoptera). ZooKeys, 493: 1-176.

Walsh, D. B., M. P. Bolda, R. E. Goodhue, A. J. Dreeves, J. C. Lee, D. J. Bruck, V. M. Walton, S. D. O'Neal \& F. G. Zalom, 2011. Drosophila suzukii (Diptera: Drosophilidae): Invasive pest of ripening soft fruit expanding its geographic range and damage potential. Journal of Integrated Pest Management, 1: 1-7.

Wang, X. G., G. Kaçar, A. Biondi \& K. M. Daane, 2016. Life-history and host preference of Trichopria drosophilae. Biological Control, 61: 387-397.

Wang, X. G. \& R. H. Messing, 2004. The ectoparasitic pupal parasitoid, Pachycrepoideus vindemmiae (Hymenoptera: Pteromalidae), attacks other primary fruit by parasitoids: host expansion and potential non-target risk. Biological Control, 31 (2): 227-236.

Westphal, V., S. O. Rizzoli, M. A. Lauterbach, D. Kamin, R. Jahn \& S. W. Hell, 2008. Video-rate far-field optical nanoscopy dissects synaptic vesicle movement. Science, 320: 246-249.

Withers, P. \& R. Allemand, 2012. The drosophilids of Rhône-Alpes (SE France) (Diptera, Drosophilidae). Bulletin de la Société Entomologique de France, 117 (4): 473-482. 